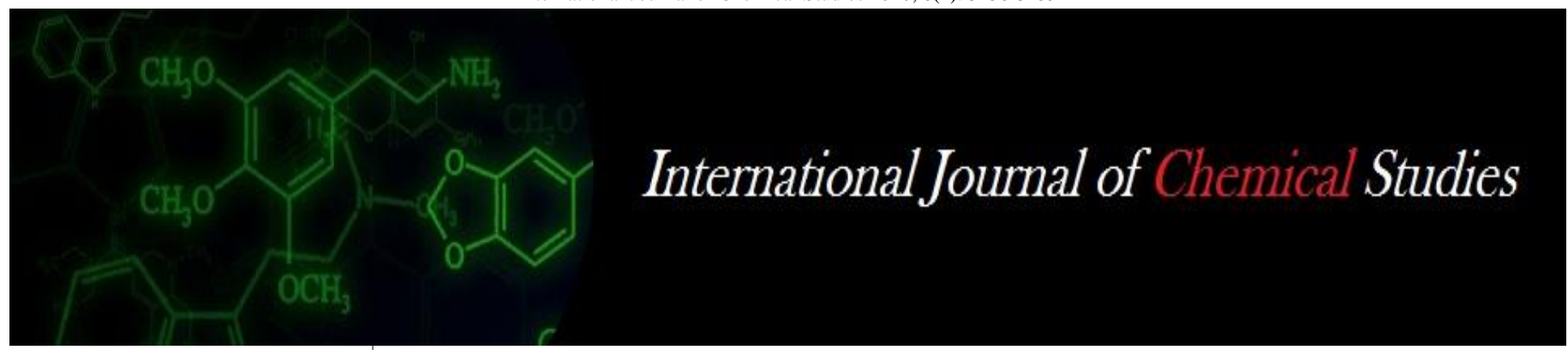

P-ISSN: 2349-8528

E-ISSN: 2321-4902

www.chemijournal.com

IJCS 2020; 8(4): 3158-3159

(C) 2020 IJCS

Received: 01-05-2020

Accepted: 03-06-2020

\section{DT Khedkar}

Department of Plant Pathology, College of Agriculture, Dapoli. Dr. Balasaheb Sawant Konkan Krishi Vidyapeeth, Dapoli, Maharashtra, India

\section{PG Borkar}

Department of Plant Pathology, College of Agriculture, Dapoli. Dr. Balasaheb Sawant Konkan Krishi Vidyapeeth, Dapoli, Maharashtra, India

\section{RA Raut}

Department of Plant Pathology, College of Agriculture, Dapoli. Dr. Balasaheb Sawant Konkan Krishi Vidyapeeth, Dapoli,

Maharashtra, India

\section{VM Karade}

Department of Plant Pathology, College of Agriculture, Dapoli. Dr. Balasaheb Sawant Konkan Krishi Vidyapeeth, Dapoli, Maharashtra, India

\section{RA Karande}

Department of Plant Pathology, College of Agriculture, Dapoli. Dr. Balasaheb Sawant Konkan Krishi Vidyapeeth, Dapoli, Maharashtra, India

\section{Corresponding Author:}

\section{DT Khedkar}

Department of Plant Pathology, College of Agriculture, Dapoli. Dr. Balasaheb Sawant Konkan Krishi Vidyapeeth, Dapoli, Maharashtra, India

\section{Integrated management of blast disease of rice}

\author{
DT Khedkar, PG Borkar, RA Raut, VM Karade and RA Karande
}

DOI: $\underline{\text { https://doi.org/10.22271/chemi.2020.v8.i4am.10135 }}$

Abstract

Field application of burnt rice husk ash, foliar sprays with silicon, chitosan, tricyclazole and neemazal were evaluated in possible combinations to assess the integrated effect of these combinations on leaf blast severity on susceptible variety Ratnagiri-24. Least PDI (21.85\%) was recorded in treatment T5 (burnt rice husk ash @ $4 \mathrm{t} / \mathrm{ha}+3$ sprays of tricyclazole 75\% WP @ 0.1\%) followed by T2 (burnt rice husk ash@ 4 t/ha + 2 sprays of silica 5\% WS @ 0.4\%) (30.00\%). Highest grain yield (33.37 q/ha)was recorded in treatment T5 (burnt rice husk ash @ 4 t/ha +3 sprays of tricyclazole 75\% WP @ 0.1\%) followed by T2 (burnt rice husk ash @ 4 t/ha + 2 sprays of silica 5\% WS @ 0.4\%) (30.41 q/ha).

Keywords: Rice blast, management, silicon, neemazal, chitosan

\section{Introduction}

Rice (Oryza sativa L.) is the most important staple food grain crop of the world which constitutes the principle food for about 60 per cent of the world's population. It contributes 43 per cent of total food grain production and 46 per cent of total cereal production in India. In Maharashtra state, rice is cultivated on an area of 15.13 lakh hectares in four regions viz., Vidharbha (7.95 L ha.), Konkan (3.83 L ha.), Western Maharashtra (3.23 L ha.) and Marathwada (0.12 L ha.) with annual production of $41.71 \mathrm{~L}$ tonnes unmilled (brown rice) and $28.78 \mathrm{~L}$ tonnes milled rice. Highest productivity was recorded in Konkan region i.e. 2.75 tonnes ha milled rice and 3.83 tonnes ha unmilled (brown rice) with total production of 15.26 $\mathrm{L}$ tonnes unmilled (brown rice) and $10.53 \mathrm{~L}$ tonnes milled rice from $3.83 \mathrm{~L}$ ha area (Anonymous, 2015). Rice is a crop of Asian origin. It belongs to family Poaceae with two species, Oryza sativa and $O$. glaberrima. $O$. sativa is a native of tropical and subtropical southern Asia while $O$. glaberrima is a native of West Africa. Studies have suggested that there are three races of Oryza sativa cultivars viz. Indica, Javonica and Japonica. The blast pathogen Pyricularia grisea (Cooke) Sacc. is the anamorph of Magnaporthe grisea Barr which is an Ascomycetes. It has potential to attack the plant in all stages of growth. The infected host initially manifests the infection in form of typical elliptical to spindle shaped spots with dark reddish brown margin and ashy grey centre. Lesions may enlarge and coalesce, growing together, to kill the entire leaves. The disease primarily occurs on nursery seedlings.

\section{Materials and Methods}

This experiment comprised of use of burnt rice husk as a basal dose, alone and in combination with sprays of fungicide, silicon, chitosan and neemazal. The field experiment was laid out during Rabi, 2015-16 and Rabi, 2016-17 in RBD with seven treatments and each treatment was replicated thrice using rice variety Ratnagiri-24 at Agricultural research station, Shirgaon. District- Ratnagiri. All the recommended agronomic practices were followed. For foliar spraying, Monomeric silicon, chitosan, tricyclazole and neemazal were dissolved in water and homogenized spray solution was sprayed in the evening hours to avoid exposure to hot sunshine. Silicon was sprayed at 15, 30 and 45 DAT, while chitosan, tricyclazole and neemazal were sprayed at 30, 45 and 55 DAT. Data were recorded visually by observing the symptoms. Five plants from five hills were selected randomly from each plot and labelled for easy detection of their location while recording the observations. The parameters considered for this study were: (i) Total number of tillers per hill, (ii) Diseased tillers per hill, (iii) Total number of leaves per hill, (iv) Diseased leaves per hill and (v) Per cent diseased leaf area was determined by following the Standard Evaluation System (0-9 SES scale) for rice blast (IRRI, 1996). 
For calculating blast intensity in a field, plants were observed at five points along a diagonal transect (IRRI, 1996). Points were selected randomly at five places. At each point, five hills were examined for disease symptoms. Actual incidence of disease in a field was then recorded as percentage of infected plants/tillers/leaves per hill out of total plants examined Per cent Disease Incidence/Intensity and Per cent Disease Index (PDI) was calculated by following formula (Wheeler, 1969) [5].

$$
\begin{aligned}
& \text { No. of dis. tillers/leaves per hill } \\
& \% \text { Disease incidence }=\frac{}{\text { Total No. of tillers/leaves per hill }} \times 100 \\
& \text { PDI }=\frac{\text { Sum of individual ratings }}{\text { No. of leaves assessed }} \times \frac{100}{\text { Maximum disease grade value }} \\
& \text { PDI in control - PDI in treatment } \\
& \% \text { Disease control }(\mathrm{PDC})=
\end{aligned}
$$

\section{Results and Discussion}

Data presented in Table 1 revealed that, during rabi, 2015-16 the lowest terminal disease incidence $(30.46 \%)$ was noticed in treatment T5 (burnt rice husk ash @ 4 t/ha +3 sprays of tricyclazole 75\% WP @ 0.1\%) which was significantly superior over rest of all the treatments followed by treatment T2 (burnt rice husk ash @ 4 t/ha +2 sprays of silica 5\% WS @ 0.4\%) (35.63\%) and T3 (burnt rice husk ash @ 4 t/ha + 1 spray of silica 5\% WS @ 0.4\%) (35.77 per cent). Next in the order was T6 (burnt rice husk ash @ 4 t/ha +3 sprays of neemazal 5\% EC @ 0.2\%) (43.62\%) and T1 (burnt rice husk ash @ 4 t/ha) (45.99\%), while in treatment T7 (untreated control), highest disease incidence (62.34\%) was recorded.

Treatment T5 (burnt rice husk ash @ 4 t/ha +3 sprays of tricyclazole 75\% WP @ 0.1\%) recorded lowest (34.86\%) disease incidence which was significantly superior over rest of the treatments. In order, next superior treatment was T3 (burnt rice husk ash @ 4 t/ha + 1 spray of silica 5\% WS @ $0.4 \%)(35.25 \%)$. It was followed by treatment T2 (burnt rice husk ash@ 4 t/ha + 2 sprays of silica 5\% WS @ 0.4\%) (35.27\%), T6 (burnt rice husk ash @ 4 t/ha +3 sprays of neemazal 5\% EC @ 0.2\%) (39.29\%) and T1 (burnt rice husk ash@ 4 t/ha) (40.98\%). Both these treatments (T6 and T1) were statistically undifferentiable. Treatment T7 (untreated control) has recorded highest $(46.03 \%)$ disease incidence during rabi, 2016-17.

Pooled lowest disease incidence (32.66 per cent) was recorded in treatment T5 (burnt rice husk ash @ $4 \mathrm{t} / \mathrm{ha}+3$ sprays of tricyclazole 75\% WP @ 0.1\%) which was found significantly superior over treatment T2 (burnt rice husk ash @ $4 \mathrm{t} / \mathrm{ha}+2$ sprays of silica $5 \%$ WS @ $0.4 \%)(35.45 \%)$. It was followed by treatment T3 (burnt rice husk ash@ 4 t/ha + 1 spray of silica 5\% WS @ 0.4\%) (35.48\%), T6 (burnt rice husk ash @ 4 t/ha +3 sprays of neemazal 5\% EC @ 0.2\%) $(41.39 \%)$ and treatment T4 (burnt rice husk ash @ $4 \mathrm{t} / \mathrm{ha}+3$ sprays of chitosan 10\% WS @ 0.2\%) (43.46 per cent). However, the highest incidence $(52.96 \%)$ was recorded in treatment T7 (untreated control). Tripathi and Jain (2005) ${ }^{[4]}$ used commercial neem plant derived products Wanis $(2.5$ 1/ha), Achook (2.5 1/ha) and Neemgold (1 1/ha) which significantly reduced the leaf blast severity by $23.29 \%$, $21.26 \%$ and $20.88 \%$, respectively and also increased the grain yield. Neem leaf extract was found significantly superior in reducing leaf $(27.16 \%)$ and neck $(47.15 \%)$ blast incidence with highest grain yield $(2300 \mathrm{~kg} / \mathrm{ha})$ as compared to untreated control Gohel et al. (2009) ${ }^{[3]}$.

Silicon application in WS form $(0.4 \%)$ was also used for the management of rice blast and it recorded 42.96 per cent reduction in disease intensity. Ashtiani et al. (2012) ${ }^{[2]}$ applied silicon to the soil prior to planting using two sources which were silica gel $(0,60,120,180 \mathrm{gm} / 5 \mathrm{~kg}$ soil $)$ and liquid sodium silicate $(0,1,2,3 \mathrm{~mL} / \mathrm{l})$. The highest reduction $(75 \%)$ in disease severity was observed in plants receiving silica gel application at the rate of $120 \mathrm{gm}$. Rodriguez et al. (2007) [1] treated rice seeds with chitosan and hydrolyzed chitosan at 100,500 and $1000 \mathrm{mg} / \mathrm{L}$. The highest control $(0=$ no lesions $)$ of $P$. grisea in rice seedlings was observed at $1000 \mathrm{mg} / \mathrm{L}$ in both Chitosan and hydrolyzed chitosan treated leaves. The highest chitosan concentration $(1000 \mathrm{mg} / \mathrm{L})$ induced the

\begin{tabular}{|c|c|c|c|c|}
\hline \multirow{2}{*}{ Sr. No. } & \multirow{2}{*}{ Treatments } & \multicolumn{3}{|c|}{ Per cent disease incidence } \\
\hline & & 2015-16* & 2016-17* & Pooled* \\
\hline 1 & T1=Burnt rice husk ash @ 4 tone/ha & $45.99(42.70)$ & $40.98(39.79)$ & $43.36(41.18)$ \\
\hline 2 & $\mathrm{~T} 2=\mathrm{T} 1+2$ sprays of silica 5\% WS @ $0.4 \%$ & $35.63(36.64)$ & $35.27(36.43)$ & $35.45(36.54)$ \\
\hline 3 & T3=T1+1 spray of silica 5\% WS @ 0.4\% & $35.77(36.73)$ & $35.25(36.41)$ & $35.48(36.55)$ \\
\hline 4 & $\mathrm{~T} 4=\mathrm{T} 1+3$ sprays of chitosan $10 \% \mathrm{WS} @ 0.2 \%$ & $46.19(42.81)$ & $44.09(41.59)$ & $43.46(41.24)$ \\
\hline 5 & $\mathrm{~T} 5=\mathrm{T} 1+3$ sprays of tricyclazole $75 \%$ WP @ $0.1 \%$ & $30.46(33.49)$ & $34.86(36.18)$ & $32.66(34.86)$ \\
\hline 6 & T6=T1+3 sprays of neemazal 5\% EC @ $0.2 \%$ & $43.62(41.33)$ & $39.29(38.81)$ & $41.39(40.04)$ \\
\hline 7 & $\mathrm{~T} 7=$ Untreated Control & $62.34(52.15)$ & $46.03(42.72)$ & $52.96(46.70)$ \\
\hline & $\mathrm{SE}(\mathrm{m})+$ & 0.79 & 0.77 & 0.54 \\
\hline & CD @ 5\% & 2.43 & 2.36 & 1.68 \\
\hline
\end{tabular}
highest enzymatic response. The findings of present study revealed only 23.24 per cent control of rice blast by application of WS chitosan.

Table 1: Effect of different treatments on the incidence of rice blast (Cv. Ratnagiri-24) under field condition (Rabi, 2015-16 and 2016-17).

*Mean of three replications; Values in parenthesis are angular transformed values

\section{References}

1. Rodriguez AT, Ramirez MA, Cardenas RM, Hernandez AN, Velazquez MG, Bautista S. Induction of defense response of Oryza sativa L. against Pyricularia grisea (Cooke) Sacc. by treating seeds with chitosan and hydrolyzed chitosan. Pesticide Biochemistry and Physiology. 2007; 89:206-215.

2. Ashtiani FA, Kadir JB, Selamat AB, Hanif AHBM, Nasehi A. Effect of foliar and root application of silicon against rice blast fungus in MR219 rice variety. The Plant Pathology Journal. 2012; 28:164-171.
3. Gohel NM, Chauhan HL, Mehta AN. Field evaluation of fungicides, bio-agents and botanicals against blast of rice. Journal of Plant Disease Sciences. 2009; 4(2):164 -166.

4. Tripathi SK, Jain AK. Evaluation of Bio-pesticides and fungicides for leaf blast and seed discoloration of rice. Plant Protection Bulletin. 2005; 57(3):20-21.

5. Wheeler BEJ. An introduction to Plant Diseases. John Wiley and Sons Ltd., London, 1969, 301.

6. Anonymous. Annual Maharashtra State Rice Workshop Progress Report held during 4-5 March, 2014. 2015, 12. 